\title{
Analisa Makanan Tradisional Jeruk Maman Dari Daun Maman (Cleome gynandra L)
}

\author{
Sahira' ${ }^{1)}$, Sri Hilma Siregar ${ }^{\star 2)}$, Rahmadini Syafri ${ }^{3)}$, Hasmalina $^{4)}$
}

1,2,3,4 Prodi Kimia, Fakultas MIPA \& Kesehatan, Universitas Muhammadiyah Riau, Pekanbaru, Provinsi Riau

Correspondence Email : $\underline{\text { rrihilma@umri.ac.id }}^{\star}$

\begin{abstract}
Jeruk Maman is a pickled vegetable that produces lactic acid, so it has a distinctive taste. The purpose of this study was to determine the food quality of jeruk maman from three variations of jeruk maman. This study used an experimental method, namely adding different amounts of chili and salt to jeruk maman. Jeruk maman are made in three variations, namely: DKA $01=500$ gr maman leaves, plus $2 \%$ rice DKA $02=500 \mathrm{~g}$ maman leaves, rice $2 \%$ salt $2.25 \%$ and $1 \%$ chili, DKA $03=500$ gr maman leaves addition of rice $2 \%$ salt $2.5 \%$ and chili $1 \%$. Let stand for 3 days, then analyzed ( $\mathrm{pH}$, moisture content, total lactic acid, lactic acid bacteria and protein) for all treatments. This study used a nonfactorial Completely Randomized Design (CRD) with 1 tested factor consisting of 3 levels of treatment and 2 repetitions. Research results The best quality of the three variations of maman oranges, namely in the analysis of protein content, the best quality is the DKA 01 sample with the highest protein amount of $2.47 \%$ and the highest titrated total acid value is also in the DKA 01 sample of $0.37 \%$. Meanwhile, the best $p H$ analysis was DKA 02 , namely $3.9 \%$ and DKA 03 , namely $3.8 \%$. The best LAB analysis results were DKA $021.7 \times 108$ and DKA 03 samples $1.5 \times 108$.
\end{abstract}

Key words: Vegetable Asinan, LAB, Water Content, Jeruk Maman, Protein.

\begin{abstract}
Abstrak
Jeruk maman merupakan asinan sayur yang menghasilkan asam laktat, sehingga mempunyai cita rasa yang khas.. Tujuan dari penelitian ini adalah untuk mengetahui kualitas makanan Jeruk maman dari tiga variasi jeruk maman. Penelitian ini menggunakan metode eksperimen, yaitu melakukan penambahan cabai dan garam dalam jumlah yang berbeda pada jeruk maman. Jeruk maman yang dibuat sebanyak tiga variasi yaitu: DKA $01=$ daun maman $500 \mathrm{gr}$, ditambah nasi $2 \%$ DKA $02=$ daun maman 500 gr penambahan, nasi $2 \%$ garam $2,25 \%$ dan cabai $1 \%$, DKA $03=$ daun maman 500 gr penambahan nasi $2 \%$ garam $2,5 \%$ dan cabai $1 \%$. Diamkan selama 3 hari, selanjutnya di analisa ( $\mathrm{pH}$, kadar air, total asam laktat, bakteri asam laktat dan protein) untuk semua perlakuan. Penelitian ini menggunakan bentuk Rancangan Acak Lengkap (RAL) non-faktorial dengan 1 faktor yang diuji terdiri dari 3 taraf perlakuan dan 2 kali ulangangan. Hasil penelitan Kualitas yang terbaik dari ketiga variasi jeruk maman yaitu pada analisa kadar protein kualitas yang terbaik adalah sampel DKA 01 dengan jumlah protein tertinggi yaitu $2,47 \%$ dan nilai total asam tertitrasi tertinggi juga pada sampel DKA 01 yaitu $0,37 \%$. Sementara pada analisa pH terbaik adalah sampel DKA 02 yaitu $3,9 \%$ dan DKA
\end{abstract}

Received: April 2021, Accepted : Mai 2021 - Jurnal Photon Vol.11 No.2

DOI : https://doi.org/10.37859/jp.v17i2.2513

PHOTON is licensed under a Creative Commons Attribution-ShareAlike 4.0 International

License 
03 yaitu 3,8 \%. Hasil analisa BAL terbaik adalah sampel DKA $021,7 \times 10^{8}$ dan DKA 03 yaitu $1,5 \mathrm{x}$ $10^{8}$.

Kata Kunci : Asinan Sayur, BAL, Kadar Air, Jeruk Maman, Protein.

\section{Introduction}

Pengolahan pangan dengan berbagai macam teknik banyak dilakukan. Salah satu teknik pengolahan pangan adalah pembuatan asinan sayur. Asinan sayur dapat menambah keanekaragaman pangan dan menghasilkan produk dengan cita rasa, aroma, serta tekstur yang khas, selain itu juga dapat memperpanjang masa simpan produk. Bahan nabati seperti kacangkacangan, buah dan sayur-sayuran mempunyai nilai gizi seperti protein, karbohidrat, kolesterol yang rendah, vitamin, dan mineral. Selain itu, kelebihan bahan nabati dibandingkan susu hewani adalah bahan nabati memilik senyawa antioksidan (karotenoid dan isoflavon) [1]. Asinan sayuran telah dikenal selama berabad-abad di beberapa negara Asia. Ada beberapa produk asinan sayur ditemukan di negara-negara Asia seperti asinan sawi (Burong mustala-Philippines, Dakguandong-Thailand, Inziangsang-India, Sayur asin-Indonesia), asinan kubis dan petsai (Dhamuoi-Vietnam, Gundruk-India, Kimchi-Korea, Paocai-China, Suan-tsai Taiwan) dan Sauerkraut adalah asinan sayuran dari Amerika Serikat dan beberapa negara Eropa[2].

Maman (Cleome gynandra) tumbuhan ini dikenal dengan beberapa nama antara lain: mamang, lenglengan, dan maman orang luar negri menegenalinya dengan nama Five-Leaved Clove, Spiderman Flower, dan bastrad mustad. Tanaman ini biasa tumbuh di sekitar sawah, merupakan tumbuhan yang hidup liar di lapangan dan pekarangan-pekarangan dan sering dianggap sebagai gulma pengganggu tanaman pertanian sehingga tanaman sering dibuang bahkan dimusnahkan dan tidak di maanfaatkan secara baik karena masih banyak yang kurang tau khasiat serta kegunaanya, oleh karena itu dibutuhkan penenganan lanjut untuk meningkatakan nilai jual dan minat masyarakat pada tanaman maman dengan cara mengolah daun maman menjadi makanan (Jeruk maman). Jeruk maman merupakan asinan sayur yang terbuat dari daun maman. Produk Asinan sayuran yang terkenal saat ini yaitu seperti kimchi (Korea), sauerkraut (Jerman), pikel,

Received: April 2021, Accepted : Mai 2021 - Jurnal Photon Vol.11 No.2 DOI : https://doi.org/10.37859/jp.v17i2.2513

PHOTON is licensed under a Creative Commons Attribution-ShareAlike 4.0 International License 
acar dan sayur asin. Sauerkraut dapat dibuat dari berbagai jenis sayuran seperti genjer, sawi, kol atau kubis, kangkung, dan rebung [3].

Asinan merupakan salah satu olahan sayuran dan buah-buahan yang dikonsumsi dalam keadaan mentah. Makanan ini merupakan hidangan sehat, kaya antimikroba dan antioksidan. Asinan juga mengandung zat penangkal kanker dan hipertensi, serta membuat awet muda dan bebas osteoporosis. Asinan sayuran merupakan sayuran yang diawetkan dengan jalan fermentasi asam. Kadar garam dalam pembuatan asinan sayur harus selalu terkontrol untuk menghindari tingkat produksi asam yang tidak diinginkan. Konsentrasi garam yang terlalu tinggi akan menurunkan produksi asam. Konsentrasi garam menyebabkan bakteri asam laktat kurang dapat mengkonversi gula dan menyebabkan pertumbuhan khamir [4].

Jeruk maman merupakan makanan tambahan yang berfungsi sebagai peningkat nafsu makan, jeruk maman adalah hasil dari asinan sayur yang berlangsung secara selektif dan spontan. Jeruk maman merupakan asinan sayur yang mengandung asam laktat, sehingga mempunyai citarasa yang khas. Asam latat yang terdapat didalam jeruk maman adalah asam laktat yang dilakukan oleh bakteri Leuconostoc mesenteroides, Lactobacillus brevis, Lactobacillus plantarum, dan Pediococcus arevisae. Mikrorganisme mikroorganisme tersebut biasanya telah terdapat dalam sayuran itu sendiri. Pada proses fermentasi biasanya digunakan garam yang berfungsi untuk mencegah timbulnya bakteri lain. Disamping itu garam juga berfungsi sebagai pengekstrak sari sayuran [5].

Potensi pengembangan agroinsdustri jeruk maman perlu digali untuk mendapatkan informasi tentang hal-hal yang berhubungan dengan keterkaitan subsistem-subsistem agribisnis (hulu, usahata tani, pengolahan, pemasaran dan jasa penunjang), manfaat jeruk maman bagi kesehatan, dan daya tahan simpan. Berdasrkan penelitian yang dilakukan oleh [6], menunjukkan perlakuan terbaik terdapat pada percobaan dengan konsentrasi garam 2,5\% dan 2,25\%. Nilai rata-rata untuk perlakuan dengan konsentrasi garam 2,25\% adalah pH 3,56; TPT 7,75\%, kadar air 90,93\%, dan asam laktat $0,0096 \%$. Sedangkan nilai rata-rata yang diperoleh untuk perlakuan dengan konsentrasi garam 2,5\% adalah pH 3,69; TPT 7,55\%, kadar air 92,104\%, dan asam laktat 0,0095\%.

Received: April 2021, Accepted : Mai 2021 - Jurnal Photon Vol.11 No.2

DOI : https://doi.org/10.37859/jp.v17i2.2513

PHOTON is licensed under a Creative Commons Attribution-ShareAlike 4.0 International

License 
Variasi konsentrasi garam pada sauerkraut berpengaruh nyata terhadap kandungan total padatan terlarut (TPT), susut bobot, kadar air, asam laktat, aroma, warna, rasa, tekstur dan penerimaan keseluruhan sauerkraut. Namun tidak berpengaruh nyata terhadap $\mathrm{pH}$, sauerkraut. Penelitian yang dilakukan [7] menunjukkan bahwa Sawi asin kering merupakan sumber karbohidrat, serat, protein, vitamin C, mineral kalsium, kalium, besi, fosfor, magnesium. Sawi asin kering berpotensi sebagai probiotik karena mengandung serat dan asam laktat yang diproduksi bakteri asam laktat (BAL).

Penelitian yang telah dilakukan oleh [8], menunjukkan bahwa pada perlakuan asinan aras 12,5, 15 dan IT,5\% tidak menunjukkan adanya pengaruh yang nyata $(\mathrm{p}>0,05)$ terhadap kandungan protein kasar, lemak kasar, dan serat kasar. Rata-rata kandungan nutrisi berturut-turut sebagai berikut : protein kasar (55,32; 53,69 dan 55,07\%); lemak kasar (3,66; 3,64 dan 4,01\%); dan serat kasar (1,07; 1,05 dan 1,14\%). Penelitian yang dilakukan oleh [9], menujukkan bahwa asinan kubis yang dibuat dengan menambahkan starter Leuconostoc mesenteroides dan Lactobacillus plantarum 1 mempunyai nilai $\mathrm{pH}$, kadar asam asetat dan gula total yang lebih rendah, namun mempunyai total asam tertitrasi dan total BAL yang lebih tinggi dibandingkan asinan kubis yang dibuat hanya dengan menambahkan Leuconostoc mesenteroides. Sifat sensori asinan kubis yang disuplementasi dengan Lactobacillus plantarum 1 secara keseluruhan agak disukai hingga disukai oleh panelis dan jumlah bakteri asam laktat yang terdapat pada asinan kubis yang ditambah L.plantarum 1 mencapai 109 - 1010 CFU/ml.

Penelitian ini [10], menunjukkan perbedaan konsentrasi garam dan lama fermentasi tidak berpengaruh pada kadar air, total padatan terlarut, $\mathrm{pH}$ dan berbedanyata pada kadar vitamin $\mathrm{C}$ pada kimchi. Kombinasi perlakuan $\mathrm{K}_{2} \mathrm{H}_{2}$ (Konsentrasi garam 4\%) memiliki karakteristik mutu organoleptik aroma dan penerimaan konsumen yang paling baik terhadap kimchi sawi putih, karena memiliki rasa masam khas kimchi yang pas. Berdasarkan hal tersebut maka perlu juga dilakukan penelitian mengenai analisa $\mathrm{pH}$, Analisa Kadar Air, Analisa Total Asam, Analisa Bakteri Asam Laktat, Analisa Protein pada makanan fermentasi jeruk maman. Pada penelitian ini dilakukan penambahan cabe dan garam dengan konsentrasi berbeda-beda.

Received: April 2021, Accepted : Mai 2021 - Jurnal Photon Vol.11 No.2 DOI : https://doi.org/10.37859/jp.v17i2.2513 PHOTON is licensed under a Creative Commons Attribution-ShareAlike 4.0 International License 


\section{The Methods}

Penelitian yang akan dilakukan adalah pembuatan asinan sayur dari daun maman (jeruk maman) dengan penambahan garam dengan kosentrasi yang berbeda-beda, cabai sebagai antioksidan pada jeruk maman. Penelitian ini menggunakan metode eksperimen, yaitu melakukan penambahan cabai dan garam dalam jumlah yang berbeda pada jeruk maman. Penambahan garam dan cabai dalam adonan jeruk maman pada konsentrasi garam 2,25\%, 2,5\% dan cabai $1 \%$.

Penelitian ini menggunakan bentuk Rancangan Acak Lengkap (RAL) non-faktorial dengan 2 faktor yang diuji terdiri dari 3 taraf perlakuan dan 2 kali ulangan sebagai berikut:

$\mathrm{DKA}_{1}$ : Makanan jeruk maman tanpa penambahan garam dan cabai sebagai kontrol

$\mathrm{DKA}_{2}$ : Makanan jeruk maman dengan penambahan garam 2,25\% dan penembahan cabai $1 \%$

$\mathrm{DKA}_{3}$ : makanan jeruk maman dengan penembahangram $2.5 \%$ dan penambahan cabai $1 \%$

\section{Result and Discussion}

\section{Analisa $\mathrm{pH}$}

Hasil analisa $\mathrm{pH}$ pada jeruk maman yang diperoleh dalam penelitian ini dapat dilihat pada Tabel 1.

Tabel 1. Hasil Analisa pH pada Jeruk Maman

\begin{tabular}{ccccc}
\hline Kode Contoh & Rata-rata & CV (\%) & CV Horwitz & Syarat Mutu (\%) \\
& $(\%) \pm$ SD & & $(\%)$ & \\
\hline DKA 01 & $4^{\mathrm{a}} \pm 0$ & 0 & 3,25 & Tidak \\
DKA 02 & $3,9^{\mathrm{a}} \pm 0$ & 0 & 3,26 & dipersyaratkan \\
DKA 03 & $3,8^{\mathrm{a}} \pm 0$ & 0 & 3,27 &
\end{tabular}

Keterangan : DKA 01 = jeruk maman tanpa penembahan garam, dan cabe $1 \%$

DKA $02=$ jeruk maman penambahan garam 2,25\% dan cabe $1 \%$

DKA 03 = jeruk maman penambahan garam 2,5\% dan cabe $1 \%$

$\mathrm{SD} \quad=$ Standar Deviasi

$\mathrm{CV}=$ Coefisient Variation

Jeruk maman dengan penambahan garam dan cabe tidak berpengaruh nyata terhadap nilai $\mathrm{pH}$,

$\mathrm{F}_{\text {hitung }}<\mathrm{F}_{\text {tabel }}$ pada taraf kepercayaan 95\% maka $\mathrm{H}_{0}$ diterima. Berdasarkan hasil penelitian ini menunjukan bahwa terjadi hubungan antara fermentasi terhadap penurunan $\mathrm{pH}$. Penurunan $\mathrm{pH}$

Received: April 2021, Accepted : Mai 2021 - Jurnal Photon Vol.11 No.2

DOI : https://doi.org/10.37859/jp.v17i2.2513

PHOTON is licensed under a Creative Commons Attribution-ShareAlike 4.0 International License 
terjadi karena adanya aktivitas bakteri asam laktat yang merubah glukosa menjadi asam laktat pada proses fermentasi anaerob dan semakin lama fermentasi maka asam laktat yang dihasilkan akan semakin meningkat sehinga menyebabkan $\mathrm{pH}$ jeruk maman semakin turun. Hasil analisis $\mathrm{pH}$ jeruk maman pada setiap konsentrasi mengalami penurunan dari sampel satu dan tiga, nilai $\mathrm{pH}$ terendah diperoleh pada konsentrasi garam 2,5\%. Berdasarkan peneli [13] menyatakan bahwa sauerkraut yang baik adalah yang mengandung $\mathrm{pH}$ berkisar antara 3,56-5,71. Hal ini membuktikan bahwa $\mathrm{pH}$ jeruk maman dalam penelitian ini pada konsentrasi garam 2,25\% dan 2,5\% sudah dalam katagori tergolong baik. Hasil analisa $\mathrm{pH}$ pada jeruk maman yaitu berkisar antara 3,8-4,0\%. Semakin tinggi konsentrasi garam yang diberikan maka kandungan asam laktat semakin rendah.

\section{Analisa kadar Air}

Hasil kadar air pada makanan jeruk maman yang diperoleh dalam penelitian ini dapat dilihat pada Tabel 2.

Tabel 2. Hasil Analisa Kadar Air pada Jeruk Maman

\begin{tabular}{lcccc}
\hline Kode Contoh & Rata-rata (\%) \pm SD & CV (\%) & CV Horwitz (\%) & Syarat Mutu (\%) \\
\hline DKA 01 & $93,15^{\mathrm{a}} \pm 0,3183$ & 0,3417 & 2,0215 & Tidak \\
DKA 02 & $93,94^{\mathrm{a}} \pm 0,1204$ & 0,1282 & 2,0189 & dipersyaratkan \\
DKA 03 & $93,59^{\mathrm{a}} \pm 0,3183$ & 0,3401 & 2,0201 &
\end{tabular}

Keterangan : DKA 01 = jeruk maman tanpa penembahan garam, dan cabe $1 \%$

DKA $02=$ jeruk maman penambahan garam $2,25 \%$ dan cabe $1 \%$

DKA 03 = jeruk maman penambahan garam 2,5\% dan cabe $1 \%$

$\mathrm{SD} \quad=$ Standar Deviasi

$\mathrm{CV}=$ Coefisient Variation

Hasil analisa uji kadar air $\mathrm{F}_{\text {Hitung }}<\mathrm{F}_{\text {Tabel }}(0,05)$ pada tingkat kepercayaan 95\% maka Ho diterima. Berti tidak ada pengaruh yang signifikan antara variabel. Nilai kadar air berkisar antara 93,15\% sampai dengan 93,94\%. Kadar air yang memiliki nilai terendah pada sampel DKA 01 yaitu pada perlakuan DKA 01 (Jeruk maman tanpa penembahan garam dan cabe) dengan kadar air 15\%. Nilai

Received: April 2021, Accepted : Mai 2021 - Jurnal Photon Vol.11 No.2

DOI : https://doi.org/10.37859/jp.v17i2.2513

PHOTON is licensed under a Creative Commons Attribution-ShareAlike 4.0 International License 
kadar air tertinggi diperoleh pada perlakuan DKA 02 (jeruk maman ditambah dengan campuran cabe $1 \%$ dan garam 2,25\%) yaitu 93,94\%. Pada penelitian sebelumya (Hayati et al., 2017) perlakuan terbaik terdapat pada perlakuan dengan konsentrasi garam 2,5\%, dengan kandungan kadar air akhir yaitu sebesar $92 \%$. Kadar air dalam bahan pangan akan berubah ubah sesuai dengan lingkungannya. Hal ini terjadi karena pada pembuatan jeruk maman menggunakan air lebih banyak dibandingkan dengan penelitian sebelumnya [14], pembuatan asinan kol (sauerkraut). Asinan kol penggaraman yang digunakan adalah penggaraman kering, yaitu menggunakan garam dalam bentuk padat atau kristal. Penambahan garam dan merica dilakukan dengan cara pelumuran pada irisan kol, kemudian diaduk hingga rata. Dimasukkan ke dalam stoples kaca bening dan ditekan-tekan hingga padat. Ditutup rapat sehingga kedap udara. Sedangkan jeruk maman menggunakan penggaraman kering, yaitu dengan menggunakan garam dalam bentuk kristal. Penambahan garam dan cabe dengan cara pelumuran pada daun maman, kemudian diaduk hingga rata dan ditambah air masak dingin. Ditutup rapat hingga kedap udara dan didiamkan selama 3 hari.

\section{Analisa Total Asam Tertitrasi}

Hasil total asam tertitrasi pada jeruk maman yang diperoleh dalam penelitian ini dapat dilihat pada Tabel 3.

Tabel 3. Hasil Analisa Total Asam Tertitrasi pada Jeruk Maman

\begin{tabular}{ccccc}
\hline Kode Contoh & Rata-rata (\%) \pm SD & CV (\%) & CV Horwitz (\%) & Syarat Mutu (\%) \\
\hline DKA 01 & $0,37^{\mathrm{a}} \pm 0$ & 0 & 4,64 & $0,8-1,5$ \\
DKA 02 & $0,36^{\mathrm{a}} \pm 0$ & 0 & 4,66 & \\
DKA 03 & $0,27^{\mathrm{a}} \pm 0$ & 0 & 4,87 &
\end{tabular}

Keterangan : DKA 01 = jeruk maman tanpa penembahan garam, dan cabe $1 \%$

DKA 02 = jeruk maman penambahan garam $2,25 \%$ dan cabe $1 \%$

DKA 03 = jeruk maman penambahan garam 2,5\% dan cabe $1 \%$

$\mathrm{SD} \quad=$ Standar Deviasi

$\mathrm{CV} \quad=$ Coefisient Variation

Received: April 2021, Accepted : Mai 2021 - Jurnal Photon Vol.11 No.2

DOI : https://doi.org/10.37859/jp.v17i2.2513

PHOTON is licensed under a Creative Commons Attribution-ShareAlike 4.0 International

License 
Konsentrasi larutan garam tidak ada pengaruh nyata $(\mathrm{P}<0,05)$ pada tingkat kepercayaan $95 \%$ terhadap total asam laktat (Tabel 3). Total asam laktat tertinggi terdapat pada perlakuan DKA 01 sebesar 0,37\% dimana semakin tinggi konsentrasi larutan garam total asam laktat semakin menurun. Tabel 3 menunjukkan semakin tinggi konsentrasi larutan garam, semakin rendah total asam laktat. Hal ini dapat disebabkan karena pada konsentrasi larutan garam yang rendah, aktivitas bakteri asam lakat lebih efektif menghasilkan asam laktat dibandingkan dengan pada konsentrasi larutan garam tinggi. Bakteri asam laktat merupakan jenis bakteri asidofilus, yaitu bakteri yang toleran terhadap suasana $\mathrm{pH}$ rendah [15].

Konsentrasi garam 2,5\% (sampel DKA 03) menghasilkan kadar asam laktat lebih rendah jika dibandingkan dengan kadar asam laktat yang dihasilkan pada sampel DKA 02 konsentrasi garam 2,25\% dan tanpa garam (DKA 01). Berdasarkan penelitian sebelumnya [16] menghasilkan total asam tertitrasi dalam hal ini menggambarkan total asam laktat yang terdapat pada asinan kubis yang berkisar antara $0,25-0,41 \%$. Data ini tidak terlalu jauh berbeda dengan data total asam pada penelitian jeruk maman yaitu berjumlah $0,27-0,37 \%$. Jumlah total asam tertitrasi pada jeruk maman telah memenuhi standar mutu asinan sayur menurut SNI 01-2600-1992 dengan jumlah asam 0,8$1,5 \%$. Hal ini sesuai dengan peryataan [17], bahwa konsentrasi garam bersama dengan asam yang dihasilkan oleh asinan sayur akan menghambat pertumbuhan dari mikroorganisme yang tidak diinginkan dan menunda pelunakan jaringan sayuran yang disebabkan oleh kerja enzim, garam yang digunakan akan menarik air dan zat-zat gizi lainnya dari jaringan sayuran.

\section{Analisa Bakteri Asam Laktat}

Hasil analisa bakteri asam laktat pada jeruk maman yang diperoleh dalam penelitian ini dapat dilihat pada Tabel 4.

Tabel 4. Hasil Analisa Bakteri Asam Laktat pada Jeruk Maman

\begin{tabular}{rcccc}
\hline Kode Contoh & Rata-rata (\%) \pm SD & CV (\%) & CV Horwitz (\%) & Syarat Mutu (\%) \\
\hline DKA 01 & $120^{\mathrm{a}} \pm 1,414$ & 0,0118 & 1,95 & Tidak \\
DKA 02 & $170^{\mathrm{a}} \pm 0$ & 0 & 1,85 & dipersyaratkan
\end{tabular}

Received: April 2021, Accepted : Mai 2021 - Jurnal Photon Vol.11 No.2

DOI : https://doi.org/10.37859/jp.v17i2.2513

PHOTON is licensed under a Creative Commons Attribution-ShareAlike 4.0 International

License 


\begin{tabular}{llll}
\hline DKA 03 & $150^{\mathrm{a}} \pm 0$ & 0 & 1,88
\end{tabular}

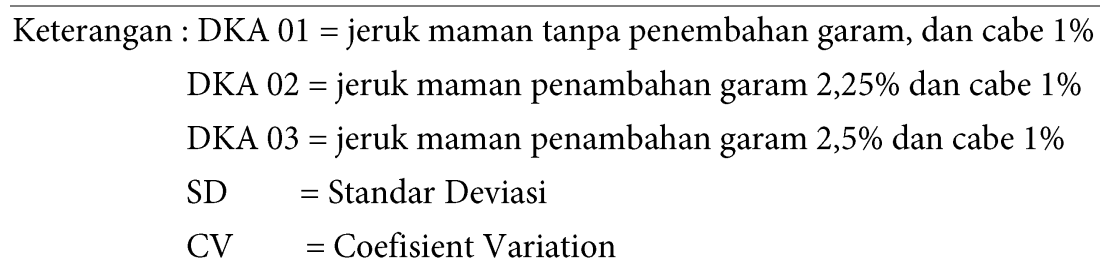

Berdasarkan Tabel 4.5 diperoleh hasil BAL dengan jumlah Koloni terbanyak yaitu DKA $011,2 \times 10^{7}$ Koloni/gr, DKA 02 1,7 x 10 $0^{8}$. Sampel DKA 02 merupakan sampel jeruk maman dengan konsentrasi penambahan garam $2,25 \%$ dan cabe $1 \%$, sedangkan sampel DKA 03 jeruk maman penambahan garam sebanyak $2,5 \%$ dan cabe $1 \%$. Kesimpulan yang dapat diambil dari hasil pemeriksaan BAL pada jeruk maman yaitu jumlah koloni tertinggi terdapat pada sampel DKA 01 dengan konsentrasi penambahan garam sebanyak $0 \%$ jumlah $1,2 \times 10^{7} \mathrm{Koloni} /$ gr. Proses asinan sayur garam memiliki peran sebagai penyeleksi mikroorganisme yang diperlukan. Jumlah BAL yang rendah $1,5 \times 10^{8}$, disebabkan karena sedikitnya sumber karbon yang terkandung dalam media, sehingga sedikit pula kandungan gula yang difermentasikan oleh bakteri. Hal ini berkaitan dengan menurunya jumlah protein pada jeruk maman. Berdasarkan analisis uji Annova $\mathrm{F}_{\text {Hitung }}<\mathrm{F}_{\text {Tabel }}(0,05)$ pada tingkat kepercayaan 95\% maka Ho diterima. Berarti tidak ada pengaruh yang signifikan antara variable 3 variasi perlakuan. Penambahan jumlah garam pada produk asinan sayur dapat mempengaruhi populasi dan jenis mikroorganisme yang tumbuh. Konsentrasi garam yang rendah, yakni 1-3\% dapat membantu pertumbuhan bakteri [4], produksi asam pada media asinan sayur tergantung pada pertumbuhan organisme dan kemampuan dalam memfermentasi karbohidrat. Jumlah total asam yang dihasilkan sesuai dengan jumlah bakteri yang tumbuh pada media. Media MRS memiliki nutrisi yang sesuai dengan kebutuhan pertumbuhan bakteri asam laktat, hal tersebut menyebabkan tingginya total asam yang dihasilkan pada media ini [18].

Received: April 2021, Accepted : Mai 2021 - Jurnal Photon Vol.11 No.2

DOI : https://doi.org/10.37859/jp.v17i2.2513

PHOTON is licensed under a Creative Commons Attribution-ShareAlike 4.0 International

License 


\section{Analisa Protein}

Hasil kadar protein pada jeruk maman yang diperoleh dalam penelitian ini dapat dilihat pada Tabel 5.

Tabel 5. Hasil Analisa Protein pada Jeruk Maman

\begin{tabular}{lcccc}
\hline Kode Contoh & Rata-rata (\%) \pm SD & CV (\%) & CV Horwitz (\%) & Syarat Mutu (\%) \\
\hline DKA 01 & $2,47^{\mathrm{a}} \pm 0,0707$ & 2,86 & 3,49 & Tidak \\
DKA 02 & $1,69^{\mathrm{b}} \pm 0,0224$ & 1,33 & 3,70 & dipersyaratkan \\
DKA 03 & $1,55^{\mathrm{c}} \pm 0,05$ & 3,26 & 3,75 &
\end{tabular}

Keterangan : DKA 01 = jeruk maman tanpa penembahan garam, dan cabe $1 \%$

DKA 02 = jeruk maman penambahan garam 2,25\% dan cabe $1 \%$

DKA 03 = jeruk maman penambahan garam 2,5\% dan cabe $1 \%$

$\mathrm{SD} \quad=$ Standar Deviasi

$\mathrm{CV} \quad=$ Coefisient Variation

Berdasarkan hasil penelitian yang diperoleh dari kadar protein menunjukkan Kadar protein jeruk maman berkisar antara 2,4\%-1,55\% . Dapat di lihat pada Tabel 5 hubungan antara konsentrasi larutan garam terhadap kadar protein, bahwa semakin besar konsentrasi larutan garam maka akan semakin kecil kadar protein yang diperoleh. Pada konsentrasi larutan garam $0 \%$ kadar protein yang diperoleh lebih besar dari pada konsentrasi larutan garam 2.25\% dan 2,5\%\%. Pada konsentrasi larutan garam $0 \%$ kadar protein yang diperoleh lebih besar dari pada konsentrasi larutan garam 2,25\% dan 2,5\%. Berdasarkan penelitian sebelumnya [19] kadar protein yang diperolah adalah $1-2,8 \%$. Sedangkan pada jeruk maman protein yang terkandung sebanyak 1,55-2,47\%. Walaupun terjadi penurunan saat penambahan garam tapi masih sesuai dengan penelitian sebelumnya. Hal ini mungkin terjadi karena kadar air yang terlalu tinggi. Menurut [20], menyatakan bahwa kadar air yang mengalami penurunan akan mengakibatkan kandungan protein didalam bahan mengalami peningkatan atau sebaliknya kadar air yang mengalami kenaikan akan mengakibatkan kandungan protein didalam bahan mengalami penurunan. Menurut [21], menyimpulkan bahwa semakin tinggi kadar air maka akan semakin rendah kadar protein yang

Received: April 2021, Accepted : Mai 2021 - Jurnal Photon Vol.11 No.2

DOI : https://doi.org/10.37859/jp.v11i2.2513

PHOTON is licensed under a Creative Commons Attribution-ShareAlike 4.0 International License 
terkandung. Hal ini disebabkan karena berkurangnya kadar air, bahan pangan akan mengandung senyawa-senyawa seperti protein, karbohidrat, lemak dan mineral dalam konsentrasi lebih tinggi.

\section{Conclusion}

Berdasarkan analisis yang telah dilakukan maka dapat disimpulkan bahwa pengaruh penambahan garam dan cabe terhadap kualitas jeruk maman sebagai berikut : Kandungan protein tertinggi pada ketiga variasi jeruk maman yaitu pada sampel DKA 01 yaitu 2,47\% sedangkan sampel DKA 02 1,69\% dan sampel DKA 03, 1,55\%. Jumlah bakteri asam laktat dengan jumlah koloni tertinggi terapat pada sampel DKA 01 dengan jumlah koloni $1,2 \times 10^{8}$, sedangkan sampel DKA $021,7 \times 10^{8}$ dan sampel DKA 03 jumlah koloni 1,5 x 108. Kualitas yang terbaik dari ketiga variasi jeruk maman yaitu DKA 01. Pada analisa kadar protein kualitas yang terbaik adalah sampel DKA 01 dengan jumlah protein tertinggi, nilai total asam tertitrasi, BAL tertinggi juga pada sampel DKA 01. Sementara pada analisa pH kualitas terbaik adalah sampel DKA 03 dan DKA 02.

\section{Pengakuan}

Penulis mangucapkan terimakasi kepada dosen pembimbing di Prodi kimia Universitas Muhammadiyah Riau, yang telah sabar dalam membimbing selama penelitain hingga selesai.

\section{References}

[1] Wandasari. B. D., Agustina. L. N. A., dan Mulyadi. N. S. 2013. Fermentasi Rumput Laut Eucheuma Cottonii Oleh Lactobacillus Plantarum. Chem Info. Vol 1, No 1.

[2] Hayati. R., Fadhil. R., dan Agustina. R. 2016. Analisis Kualitas Sauerkraut (Asinan Jerman) Dari Kol (Brassica oleracea) Selama Fermentasi Dengan Variasi Konsentrasi Garam. Jurnal Rona Teknik Pertanian. Vol 10. No (2).

[3] Shobahiya. N. 2017. Pengaruh Jenis Media Fermentasi Dan Konsentrasi Garam Terhadap Karakteristik Asinan Sawi Hijau (Brassica Rapa L). Skripsi. Program Studi Teknologi Pangan Fakultas Teknik. Universitas Pasundan. Bandung.

[4] Marsigit. W. dan Hemiyati. 2018. Ketersidiaan Bahan Baku, Kandungan Gizi, Potensi Probiotik Dan Daya Tahan Simpan Sawi Asin Kering Kabupaten Rejang Lebong Sebagai Produk Agroindustri. Jurnal Agroindustri. Vol. 8 No. 1

[5] Mukti. K. S., Rohmawati. N., dan Sulistiyani. S. 2018. Analisis Kandungan Karbohidrat, Glukosa, Dan Uji Daya Terima Pada Nasi Bakar, Nasi Panggang, Dan Nasi Biasa. Jurnal Agroteknologi. Vol. 12 No.01

Received: April 2021, Accepted : Mai 2021 - Jurnal Photon Vol.11 No.2

DOI : https://doi.org/10.37859/jp.v11i2.2513

PHOTON is licensed under a Creative Commons Attribution-ShareAlike 4.0 International 
[7] Abdullah. S., Tuljannah., dan Laela. U. 2017. Pengaruh Konsentrasi Starter Dan Konsentrasi Larutan Garam Pada Percobaan Fermentasi Biji Nangka Menjadi Tauco. Seminar Nasional Sains dan Teknologi.

[8] Sundari. D, Almashuri, dan Lamid. A. 2015. Pengaruh Proses Pemasakan Terhadap Komposisi Zat Gizi Bahan Pangan Sumber Protein. Media Litbang. Vol. 25 No (4).

[9] Amrullah. F.A, Liman, dan Erwanto. 2015. Pengaruh Penambahan Berbagai Jenis Sumber Karbohidrat Pada Silase Limbah Sayuran Terhadap Kadar Lemak Kasar, Serat Kasar, Protein Kasar Dan Bahan Ekstrak Tanpa Nitrogen. Jurnal Ilmiah Peternakan Terpadu. Vol. 3. No (4).

[10] Anggelia. I. O. 2017. Kandungan pH, Total Asam Tertitrasi, Padatan Terlarut dan VitaminC pada Makanan Fermntasi. Skripsi. Politeknik. Program Studi teknologi Hasil Pertanian.

[11] Aryanti. M, Ramlah. S, dan Yumas. M. 2019. Pengaruh Lama Fermantasi dan Pengepresan Berulang terhadap Mutu Kakao Bubuk. Jurnal Industri hasil Perkebunan. Vol.14. No. 1.

[12] Bamiwanto. A.S., Mongi. E., dan Kaseger. E. 2015. Analisa Kadar Air, Ph, Organoleptik, Dan Kapang Pada Produk Ikan Tuna (Thunnus Sp) Asap, Di Kelurahan Girian Bawah, Kota Bitung, Sulawesi Utara. Jurnal Media Teknologi Hasil Perikanan. Vol. 3, No. 2

[13 Hamdiyati, Yanti. 2011. Pertumbuhan dan Pengendalian Mikroorganisme II. Tersedia dihttp://file.upi.edu/Direktori/FPMIPA/JUR. PEND. BIOLOGI/ 196611031991012YANTI_HAMDIYATI/Pertumbuhan_pada_mikroorgan isme_II.pdf

[14] Hartono. 2009. Inventarisasi Jenis-Jenis Tumbuhan yang dapat Digunakan sebagai Bahan Praktikum Sistem Transportasi pada Tumbuhan. Bionature. Vol. 10 (2).

[15] Jamilah. M., Purnomowati., dan Dwiputranto. U. 2016. Pertumbuhan Cabai Merah (Capsicum annuum L.) pada Tanah Masam yang Diinokulasi Mikoriza Vesikula Arbuskula (MVA) Campuran dan Pupuk Fosfat. Biosfera. Vol 33. No 1

[16] Kwarteng, A.O. Abogoom, J. Adu Ammoah, R. Nyidanu, D. Nyam, C.K. Ghunny, T. Awuah, T. Ziyaaba, J.Z. Ogunsanya, J.O. Orhin, E.E. dan Asiedu, D.D. 2018. Phenomic Characterization of Twenty-Four Accessions of Spider Plant (Clemeo Gynandra L ) The Upper East Region of Ghana. Scientia Horticulturae. 124-131.

[17] Lestari. C, Suhardi. I, dan Ridwansyah. 2017. Pengaruh Konsentrasi Larutan Garam Dan Suhu Fermentasi Terhadap Mutu Kimchi Lobak. Ilmu dan Teknologi Pangan. Vol.5 No. 1

[18] Leviana. W., dan Paramita. V. 2017. Pengaruh Suhu Terhadap Kadar Air Dan Aktivitas Air Dalam Bahan Pada Kunyit (Curcuma Longa) Dengan Alat Pengering Electrical Oven. Metana. Vol. 13(2):37-44.

[19] Mardalena. 2016. Fase Pertumbuhan Isolat Bakteri Asam Laktat (BAL) Tempoyak Asal Jambi yang Disimpan Pada Suhu Kamar. Skripsi. Fakultas Perternakan. Universitas Jambi.

Received: April 2021, Accepted : Mai 2021 - Jurnal Photon Vol.11 No.2

DOI : https://doi.org/10.37859/jp.v11i2.2513

PHOTON is licensed under a Creative Commons Attribution-ShareAlike 4.0 International

License 
[20] Masdarini. L. 2016. Manfaat Dan Keamanan Makanan Fermentasi Untuk Kesehatan (Tinjauan Dari Aspek Ilmu Pangan). Jurusan Pkk (Tata Boga). FTK. Undiksha.

[21] Mumtianah. O. N., Kusdiyanti. E. dan Budiharjo. A. 2014. Isolasi, Karakterisasi Bakteri Asam Laktat, Dan Analisis Proksimat Dari Makanan Fermentasi Bekasam Ikan Mujair (Oreochromis Mossambicus Peters). Jurnal Biologi. Volume 3 No 2. Hal. 20-30

[22] Novianti. M., Tiwon. V. M. A., dan Mustapa. K. 2017. Analisis Kadar Glukosa Pada Nasi Putih Dan Nasi Jagung Dengan Menggunakan Metode Spektronik 20. Jurnal Akademika Kimia. Volume 6, No. 2, 2017: 107-112

[23] Nuraini. A., Suherman. C, Soleh. M. A., dan Annisa. N. F. 2018. Pertumbuhan dan hasil tanaman cabai (Capsicum Sp.) yang diberi pupuk hayati pada pertanaman kelapa sawit (Elaeis guineensis Jacq.) TBM I. Jurnal Kultivasi. Vol. 17 (2)

[24] Permana D.R., dan Kusmiati. 2007. Isolasi Kapang Patogen Dari Bahan Kitosan Sebagai Pengawet Makanan Snack Ubi Jalar (Ipomea Batatas, L). LIPI. Bogor.

[25] Pradani. A. 2009. Pemanfaatan Fraksi Cair Isolat Pati Ketela Pohon Sebagai Media Fermentasi Pengganti Air Tajin Pada Pembuatan Sayur Asin. Skripsi. Jurusan Teknik Kimia. Fakultas Teknik Universitas Diponegoro. Semarang.

[26] Riyansyah. A., Supriadi. A., dan Nofianti. R. 2013. Pengaruh Perbedaan Suhu Dan Waktu Pengeringan Terhadap Karakteristik Ikan Asin Sepat Siam (Trichogaster Pectoralis) Dengan Menggunakan Oven. Fishtech. Volume 11. No. 01

[25] Saputra. K. A., Pontoh. J. S., dan Momuat. L. D. 2015. Analisis Kandungan Asam Organik pada Beberapa Sampel Gula Aren. Jurnal MIPA UNSRAT. 4 (1) 69-74

[26] SNI 01-2891-1992. Cara Uji Makanan dan Minuman

[27] Ssegawa, P., Kasenene, J.M., 2007. Medicinal plant diversity and uses in the Sango bay area, Southern Uganda. J. Ethnopharmacol. Vol 113. No (3).

[28] Susanti. E., dan Hidayat. 2016. Profil Protein Susu dan Produk Olahanya. Jurnal MIPA. Vol 39. No (2).

[29] Susilowati.S, dan Handani. 2016. Uji Kimia, Mikrobiologi Dan Organoleptik Indonesian Sauerkraut Dengan Cabai Dan Bawang Putih. Seminar Nasional dan Gelar Produk.

[30] Suriyanto. 2017. Karakteristik Makanan Fermentasi Tradisional Kabupaten Sangau. Skripsi. Jurusan Budidaya Pertanian. Universitas Tanjungpuri

[31] Zainuri. M., Arwiyah., dan Efendy. M. 2015. Studi Kandungan Nacl Di Dalam Air Baku Dan Garam Yang Dihasilkan Serta Produktivitas Lahan Garam Menggunakan Media Meja Garam Yang Berbeda. Jurnal Kelautan. Volume 8, No. 1

Received: April 2021, Accepted : Mai 2021 - Jurnal Photon Vol.11 No.2

DOI : https://doi.org/10.37859/jp.v17i2.2513

PHOTON is licensed under a Creative Commons Attribution-ShareAlike 4.0 International 
[32] Yuarni. D, Kadirman, dan Jamaludin. 2015. Laju Perubahan Kadar air, Kadar Protein dan Uji Organoleptik Ikan Lele Asin Menggunakan Alat Pengering Kabinet (Cabinet drayer) dengan suhu Terkontrol. Jurnal Pendidikan Teknologi Pertanian. Vol. 1.

Received: April 2021, Accepted : Mai 2021 - Jurnal Photon Vol.11 No.2

DOI : https://doi.org/10.37859/jp.v17i2.2513

PHOTON is licensed under a Creative Commons Attribution-ShareAlike 4.0 International 